\title{
Reduced expression of IL-12 receptor $\beta 2$ and IL-18 receptor $\alpha$ genes in natural killer cells and macrophages derived from B6-mi/mi mice
}

\author{
Tatsuki R Kataoka ${ }^{1,2}$, Nobuyasu Komazawa ${ }^{3}$, Keisuke Oboki ${ }^{1}$, Eiichi Morii ${ }^{1}$ and \\ Toru Nakano ${ }^{1,4}$ \\ ${ }^{1}$ Department of Pathology, Medical School/Graduate School of Frontier Bioscience, Osaka University, Osaka, \\ Japan; ${ }^{2}$ Department of Pathology, Osaka Medical Center for Cancer and Cardiovascular Disease, Osaka, \\ Japan; ${ }^{3}$ Department of Social and Environmental Medicine, Graduate School of Medicine, Osaka University, \\ Osaka, Japan and ${ }^{4}$ Department of Molecular Cell Biology, Research Institute for Microbial Disease, Osaka \\ University, Osaka, Japan
}

\begin{abstract}
The $m i$ transcriptional factor (MITF) is a basic helix-loop-helix leucine zipper-type transcriptional factor. The $m i$ mutant allele encodes an abnormal MITF, in which one out of four consecutive arginines is deleted in the basic domain. The VGA-9-tg (tg) allele is another mutant allele and considered to be a null mutant allele. C57BL/6 (B6)$\mathrm{mi} / \mathrm{mi}$ mice showed abnormal phenotypes of natural killer (NK) cells and macrophages, whereas B6-tg/tg mice did not. The expression levels of the genes for the interleukin-12 receptor (IL-12R) $\beta 2$ and IL-18R $\alpha$ were reduced in both the NK cells and macrophages of B6- $\mathrm{mi} / \mathrm{mi} \mathrm{mice,} \mathrm{while} \mathrm{the} \mathrm{expression} \mathrm{levels} \mathrm{of} \mathrm{the} \mathrm{corresponding} \mathrm{genes}$ in B6-tg/tg mice were unaffected. The B6- $\mathrm{mi} / \mathrm{mi}$ NK cells and B6- $\mathrm{mi} / \mathrm{mi}$ macrophages showed impaired responses to stimulation with IL-12, IL-18, and IL-12 plus IL-18 stimulation. The abnormal NK cell and macrophage of B6- $\mathrm{mi} / \mathrm{mi}$ mice appear to be due to decreased expression of the IL-12R $\beta 2$ and IL-18R $\alpha$ genes. Laboratory Investigation (2005) 85, 146-153, advance online publication, 11 October 2004; doi:10.1038/labinvest.3700188
\end{abstract}

Keywords: IL-12R; IL-18R; macrophage; MITF; NK cell

The mi locus of mice encodes a member of the basic helix-loop-helix leucine zipper protein family of transcription factors, MITF., ${ }^{1,2}$ Many mutations have been reported for the mi locus. ${ }^{1,2}$ Of these, the mi mutant allele has been most intensively studied. The mi mutant allele encodes an abnormal MITF (mi-MITF), in which one out of four consecutive arginines is deleted in the basic domain. ${ }^{1,2}$ The miMITF protein is defective in DNA binding ${ }^{3}$ and nuclear localization. ${ }^{4}$ The $t g$ mutation represents another mutant allele of the mi locus. It has been shown that $\mathrm{tg} / \mathrm{tg}$ mice possess an insertional mutation in the promoter region of the mi gene, and they do not express any MITFs. ${ }^{1,2}$ Thus, $t g$ is considered to be null mutant allele.

Both B6-mi/mi and B6-tg/tg mice share certain phenotypic features, such as microphthalmia, white coat color, and abnormal mast cell phenotypes. ${ }^{1,2,5-7}$

Correspondence: Dr TR Kataoka, MD, Department of Pathology, Room C2, Osaka University Medical School, Yamaka-oka 2-2, Suita, Osaka 565-0871, Japan.

E-mail: trkata@patho.med.osaka-u.ac.jp

Received 23 June 2004; revised 27 August 2004; accepted 31 August 2004; published online 11 October 2004
These mice are distinguishable from each other in the following respect; B6-mi/mi mice showed, but B6- $\mathrm{tg} / \mathrm{tg}$ mice do not show abnormal phenotypes of the NK cell and macrophage lineage.$^{8-13}$ Both B6-mi/ $\mathrm{mi}$ and B6-tg/tg mice showed normal NK $1.1^{+}$cell development, but only B6-mi/mi mice showed impaired NK activity. ${ }^{8-10}$ Both B6-mi/mi and B6-tg/ $\mathrm{tg}$ mice showed normal distributions of osteoclasts, whereas only B6-mi/mi mice showed osteopetrosis, which results from the impaired bone-resorption abilities of their osteoclasts. ${ }^{11,12}$ In addition to the osteoclasts, the peritoneal macrophages of B6- $\mathrm{mi} / \mathrm{mi}$ mice have been reported to show some abnormal phenotypes, such as decreased phagocytic capacity and decreased acid phosphatase activity. ${ }^{13}$

Interleukin (IL)-12 and IL-18 are proinflammatory cytokines that are produced mainly by macrophages and dendritic cells in response to pathogens (reviewed in Trinchieri ${ }^{14}$ and Nakanishi et $a 1^{15}$ ). IL12 is a heterodimeric cytokine, which was originally described as NK cell stimulatory factor. ${ }^{16}$ The IL-12 receptor is composed of $\beta 1$ subunit (IL-12R $\beta 1$ ) and $\beta 2$ subunit (IL-12R $\beta 2) .{ }^{17}$ IL-12 is the major cytokine for inducing Th1-type responses. ${ }^{14,18}$ IL-12 activates NK cells and induces IFN- $\gamma$ production. ${ }^{18}$ IL-18 was 
originally identified as interferon (IFN)- $\gamma$ inducing factor. ${ }^{19}$ The receptor for IL-18 is composed of an $\alpha$ subunit (IL-18R $\alpha)^{20}$ and a $\beta$-subunit (IL-18R $\beta$ ). ${ }^{21}$ Both IL-18R $\alpha$ and IL-18R $\beta$ are belong to the IL-1R superfamily. ${ }^{15,20,21}$ In contrast to IL-12, IL-18 plays important roles in both Th1 and Th2 responses. ${ }^{15}$ In synergy with IL-12, IL-18 stimulates Th1 responses by enhancing NK activity and IFN- $\gamma$ production. $^{22}$ Both NK cells and macrophages express the receptors for both IL-12 and IL-18, and produce IFN- $\gamma$ in response to stimulation with IL-12, IL-18, and IL-12 plus IL-18. ${ }^{18,22-27}$

The abnormal phenotypes of B6-mi/mi NK cells resemble those of mice that are deficient in IL-12 or IL-18 signaling. ${ }^{8-10,18,22-27}$ The administration of IL12 or IL-18 did not recover the decreased NK activity of B6-mi/mi mice (our unpublished data). In this study, we examined the expression of IL-12R $\beta 1$, IL$12 \mathrm{R} \beta 2$, IL-18R $\alpha$ and IL-18R $\beta$ in NK cells that were derived from B6- $+/+$, B6- $\mathrm{mi} / \mathrm{mi}$, or B6-tg/tg mice. The expression levels of IL-12R $\beta 2$ and IL-18R $\alpha$ were reduced significantly in the NK cells of B6- $\mathrm{mi} / \mathrm{mi}$ mice, but not in the NK cells of B6- $t g / t g$ mice, when compared with those of B6- $+/+$ mice. IFN- $\gamma$ production in response to stimulation with IL-12, IL-18, or IL-12 plus IL-18 was also impaired in the NK cells of B6-mi/mi mice. In addition, the macrophages of B6-mi/mi mice also showed decreased expression levels of IL-12R $\beta 2$ and IL-18R $\alpha$, and had impaired IFN- $\gamma$ production. These data show that the abnormal NK cell and macrophage phenotypes of B6-mi/mi mice are due to the decreased expression of the genes for IL-12R $\beta 2$ and IL-18R $\alpha$.

\section{Materials and methods}

\section{Mice}

The original stock of B6-mil + mice was purchased from the Jackson Laboratory (Bar Harbor, ME, USA) and was maintained in our laboratory by consecutive backcrosses with our own inbred B6 colony (more than 17 generations at the time of the present experiment). B6-mi/mi mice were obtained by mating among B6-mil + mice. Mice of the $\mathrm{mi} / \mathrm{mi}$ genotype were identified by the white coat color. Most of the B6-mi/mi mice died before 4 weeks of age due to the failure of teeth eruption. To ensure the survival of B6- $\mathrm{mi} / \mathrm{mi}$ mice to 6-8 weeks of age, we fed the weaning B6-mi/mi mice with powdered chow. ${ }^{10}$

The original stock of VGA-9-tg/ + mice, in which the mouse vasopressin-Escherichia coli $\beta$-galactosidase transgene is integrated at the $5^{\prime}$ flanking region of the mi gene, ${ }^{1,2}$ were kindly provided by $\mathrm{Dr} \mathrm{H}$ Arnheiter (National Institutes of Health, Bethesda, MD, USA). The integrated transgene was maintained by repeated backcrosses to our own inbred B6 colony. B6-tg/tg mice were obtained by mating among the B6- $\mathrm{tg} /+$ mice. Mice of the $\mathrm{tg} / \mathrm{tg}$ genotype were identified by their white coat colour.

\section{Reagents}

Recombinant mouse (rm) IL-2, IL-12, M-CSF, and IFN- $\gamma$ were purchased from R\&D Systems (Minneapolis, MN, USA). rmIL-18 was purchased from MBL Co. Ltd (Nagoya, Japan). The anti-NK $1.1^{+}$antibody (Ab), anti-Mac-1 (CD11b) Ab and anti-CD16/CD32 Ab were purchased from BD Pharmingen (San Diego, CA, USA). The anti-mouse IL-12R $\beta 2$ was purchased from Santa Cruz Biotechnology (Santa Cruz, CA, USA). The anti-mouse IL-18R $\alpha$ was purchased from R\&D Systems. Phorbol 12-myristate 13-acetate (PMA) and ionomycin were provided from $\mathrm{Dr} \mathrm{K}$ Nishida (RIKEN Yokohama Institute, Yokohama, Japan).

\section{NK Cell Preparation}

Mice that were 6-8 weeks of age were used to obtain freshly isolated NK $1.1^{+}$cells. The mice were killed by decapitation after ether anesthesia, and the spleens were removed. The spleens were passed through a mesh, to prepare spleen cell suspensions. NK cells were isolated by negative selection with the MACS NK cell isolation kit (Miltenyi Biotec, Bergisch Gladbach, Germany) following the manufacturer's instructions. More than $95 \%$ of the isolated cells derived from B6- $+/+, \mathrm{B} 6-\mathrm{mi} / \mathrm{mi}$, and B6-tg/tg mice expressed the NK $1.1^{+}$antigen as confirmed by flow cytometry. Cultured NK $1.1^{+}$cells were obtained by the method described previously. ${ }^{10}$

\section{Peritoneal Macrophage Isolation}

Mice that were 6-8 weeks of age were used to obtain peritoneal macrophages. A volume of $5 \mathrm{ml}$ of phosphate-buffered saline (PBS) was injected into the peritoneal cavity, and the abdomen was massaged gently. The peritoneal cavity was carefully opened, and the fluid that contained the peritoneal macrophages was aspirated with a Pasteur pipette. The collected cells were cultured for $1 \mathrm{~h}$ in a $\alpha$ minimal essential medium ( $\alpha$-MEM; ICN Biomedicals, Costa Mesa, CA, USA) supplemented with 10\% FCS. Nonadherent cells were removed, and the adherent cells were used as peritoneal macrophages. In total, $72 \pm 5 \%$ of peritoneal macrophages derived from $\mathrm{B} 6-+/+, 68 \pm 6 \%$ of $\mathrm{B} 6-\mathrm{mi} / \mathrm{mi}$, or $69 \pm 5 \%$ of B6- $\mathrm{tg} / \mathrm{tg}$ mice were Mac-1 ${ }^{+}$, as confirmed by immunocytochemical method.

\section{Mac-1 ${ }^{+}$Cells Preparation}

Cultured Mac-1 ${ }^{+}$cells were obtained by the standard techniques. ${ }^{28}$ Mice that were 3-4 weeks of age were used to obtain cultured Mac- $1^{+}$cells. Spleen cell suspensions were suspended in $\alpha$-MEM medium that was supplemented with 10\% FCS and $25 \mathrm{ng} / \mathrm{ml} \mathrm{rmM}-\mathrm{CSF}$. Spleen cells that were derived from B6- + / + , B6-mi/mi, or B6-tg/tg mice expressed normal levels of the M-CSF receptor gene. ${ }^{29}$ More 
than $95 \%$ of the cultured adherent cells derived from $\mathrm{B} 6-+/+, \mathrm{B} 6-\mathrm{mi} / \mathrm{mi}$, or B6-tg/tg mice were Mac- $1^{+}$, as confirmed by immunocytochemistry and flow cytometry.

\section{Reverse Transcription-Polymerase Chain Reaction (RT-PCR)}

Reverse transcription-polymerase chain reaction (RT-PCR) was used to evaluate the expression levels of IL-12R and IL-18R. Total RNAs $(10 \mu \mathrm{g})$ was extracted from freshly isolated NK $1.1^{+}$cells and cultured $\mathrm{Mac}^{-} 1^{+}$cells that were derived from B6- $+/+$, B6-mi/mi or B6-tg/tg mice. The extracted RNAs were subjected to reverse transcription by Superscript (Invitrogen, Carlsbad, CA, USA), and the single-stranded cDNAs were obtained. Subsequently, $0.1 \mu \mathrm{l}$ of the reaction mixture was added to $25 \mu \mathrm{l}$ of PCR mixture containing $1.25 \mathrm{U}$ of Taq DNA polymerase (Roshe Diagnostics, Manheim, Germany) 25 pmol of each of the primers. The following (forward and reverse) primers were used: IL-12R $\beta 1 \quad 5^{\prime}$ AATGTGCTCGCCAAAACTCG and $3^{\prime}$ CGCAGTCTTATGGGTCCTCC; IL-12R $\beta 25^{\prime}$ ACATT ACTGCCATCACAGAG and $3^{\prime}$ AGGAGATTATCCGT AGGTAG; IL-18R $\alpha$ 5' GTGCACAGGAATGAAACA GC and $3^{\prime}$ ATTTAAGGTCCAATTGCGACGA; IL18R $\beta 5^{\prime}$ GGAGTGGGAAATGTCAGTAT and $3^{\prime}$ CCGT GCCGAGAAGGATGTAT; $\beta$-actin $5^{\prime}$ TAAAGACCTCT ATGCCAACAC and $3^{\prime}$ CTCCTGCTTGCTGATCCAC AT. Each PCR cycle parameters were denaturation $20 \mathrm{~s}$ at $95^{\circ} \mathrm{C}$, annealing $30 \mathrm{~s}$ at $52^{\circ} \mathrm{C}$ and polymerase reaction $1 \mathrm{~min}$ at $72^{\circ} \mathrm{C}$. For semiquantitative PCR, the fragments of IL-12R $\beta 1$, IL-12R $\beta 2$, IL-18R $\alpha$ or IL$18 \mathrm{R} \beta$ were amplified with 28 cycles out of RT products derived from NK $1.1^{+}$cells and with 32 cycles out of that of Mac- $1^{+}$cells. The fragments of $\beta$-actin were amplified with 22 cycles out of RT products derived from both freshly isolated NK $1.1^{+}$ cells and cultured Mac- $1^{+}$cells. Aliquots $(10 \mu \mathrm{l})$ of the PCR products were electrophoresed on a $1 \%$ agarose gel that contained ethidium bromide.

\section{Flow Cytometry}

For the determination of IL- $12 \mathrm{R} \beta 2$ or IL- $18 \mathrm{R} \alpha$ expression, we incubated freshly isolated NK $1.1^{+}$ cells and cultured Mac- $1^{+}$cells for 3 days with or without IFN- $\gamma(20 \mathrm{ng} / \mathrm{ml})$. Cells were harvested and washed with PBS twice. After Fc receptor blocking using anti-CD16/CD32 Ab, the cells were incubated with anti-mouse IL-12R $\beta 2$ or anti-mouse IL-18R $\alpha$ followed by FITC-conjugated anti goat IgG Ab. Stained cells were analyzed using FACScan (Becton Dickinson, Los Angeles, CA, USA).

\section{Cytokine Measurements}

Freshly isolated $\left(1 \times 10^{5}\right.$ cells $\left./ \mathrm{ml}\right)$ or cultured NK cells $\left(2 \times 10^{4}\right.$ cells $\left./ \mathrm{ml}\right)$ were recultured for $5 \mathrm{~h}$ in 24-well plates, together with rmIL-12 $(20 \mathrm{ng} / \mathrm{ml})$, rmIL-18 $(20 \mathrm{ng} / \mathrm{ml})$, and rmIL-12 plus rmIL-18. Peritoneal macrophages $\left(5 \times 10^{5}\right.$ cells $\left./ \mathrm{ml}\right)$ or cultured $\mathrm{Mac}-1^{+}$cells $\left(5 \times 10^{4}\right.$ cells $\left./ \mathrm{ml}\right)$ were recultured for $5 \mathrm{~h}$ in 24-well plates with rmIL-12 (20 ng/ $\mathrm{ml})$, rmIL-18 $(20 \mathrm{ng} / \mathrm{ml})$, rmIL-12 plus rmIL-18. Cultured NK cells $\left(2 \times 10^{4}\right.$ cells $\left./ \mathrm{ml}\right)$ or cultured Mac- $1^{+}$cells $\left(5 \times 10^{4}\right.$ cells $\left./ \mathrm{ml}\right)$ were recultured for $5 \mathrm{~h}$ in the presence of $50 \mathrm{ng} / \mathrm{ml}$ PMA and $1 \mu \mathrm{M}$ ionomycin. ${ }^{30}$ The culture supernatants were assayed using an ELISA kit for IFN- $\gamma$ (R\&D) according to the manufacturer's instructions.

\section{Perforin (Pfn) Expression Assay}

The cultured NK $1.1^{+}$cells were recultured for $24 \mathrm{~h}$ at $1 \times 10^{5}$ cells $/ 200 \mu \mathrm{l}$ in 96 -well plates, together with rmIL-12 $(0.1,1,10,100$, or $1000 \mathrm{ng} / \mathrm{ml})$ and rmIL-18 $(0.1,1,10,100$, or $1000 \mathrm{ng} / \mathrm{ml})$. Total RNA samples were extracted from the cultured cells, and RT-PCR was performed as described above. The following PCR primers were used: Pfn $5^{\prime}$ TGCCA CTCGGTCAGAATGCAAGC and $3^{\prime}$ CTTCCAGTAAT GTGTGCAGGGGC. Cycle parameters were denaturation $30 \mathrm{~s}$ at $95^{\circ} \mathrm{C}$, annealing $30 \mathrm{~s}$ at $50^{\circ} \mathrm{C}$ and polymerase reaction $1 \mathrm{~min}$ at $72^{\circ} \mathrm{C}$. The fragments of Pfn were amplified with 30 cycles. The fragments of $\beta$-actin were amplified with 22 cycles, and used as control. Aliquots $(10 \mu \mathrm{l})$ of the PCR products were electrophoresed on $1 \%$ agarose gel that contained ethidium bromide.

\section{Results}

\section{Reduced Expression of the IL-12R and IL-18R Genes in NK Cells and Macrophages of B6-mi/mi Mice}

We analyzed the expression of the IL-12R and IL18R genes in freshly isolated NK $1.1^{+}$cells and cultured Mac- $1^{+}$cells that were derived from the spleen of B6- $+/+$, B6- $\mathrm{mi} / \mathrm{mi}$, and B6- $\mathrm{tg} / \mathrm{tg}$ mice, using semiquantitative RT-PCR. The levels of IL$12 \mathrm{R} \beta 2$ and IL-18R $\alpha$ mRNA were reduced significantly in cells from B6-mi/mi mice, as compared to cells from B6- $+/+$ and B6- $\mathrm{tg} / \mathrm{tg}$ mice (Figures 1a and $2 \mathrm{a}$ ). In contrast, the levels of IL-12R $\beta 1$ and IL$18 \mathrm{R} \beta$ mRNA were comparable in the cells of these mutant and control mice (Figures 1a and 2a).

The expression of IL- $12 \mathrm{R} \beta 2$ and IL-18R $\alpha$ was analyzed at the protein level by flow cytometry. As shown in Figures $1 \mathrm{~b}$ and $2 \mathrm{~b}$, the surface expression levels of IL-12R $\beta 2$ and IL-18R $\alpha$ were reduced significantly in freshly isolated NK $1.1^{+}$NK cells and cultured Mac- $1^{+}$cells that were derived from B6-mi/mi mice. IFN- $\gamma$ has been reported to enhance expression of IL-12R (reviewed in Trinchieri ${ }^{14}$ ). But IFN- $\gamma$ administration did not increase the expression of IL-12R $\beta 2$ gene on freshly isolated NK $1.1^{+} \mathrm{NK}$ cells or cultured Mac- ${ }^{+}$cells derived from B6-mi/ mi mice (Figures $1 \mathrm{~b}$ and $2 \mathrm{~b}$ ). And cultured NK cells and peritoneal macrophages (about $70 \% \mathrm{Mac}^{-1}{ }^{+}$) 
a

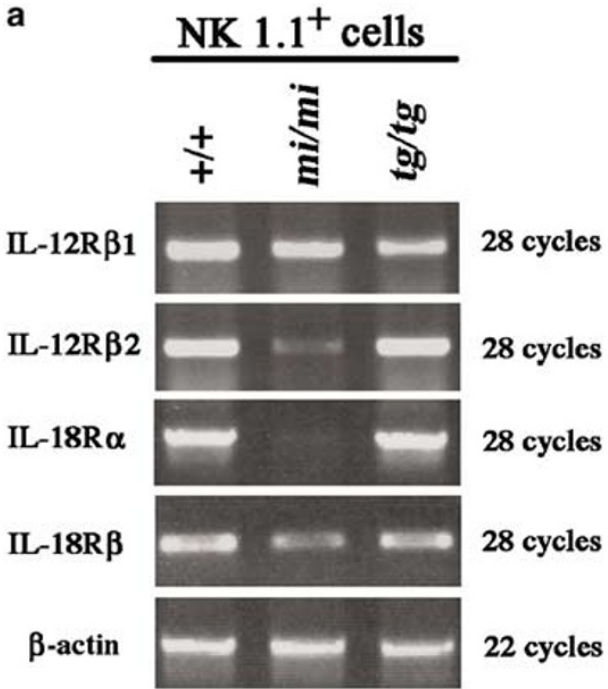

b
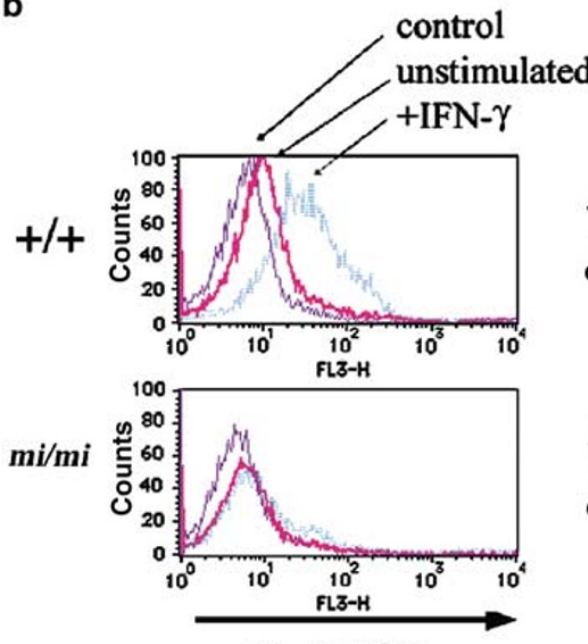

IL-12Rß2
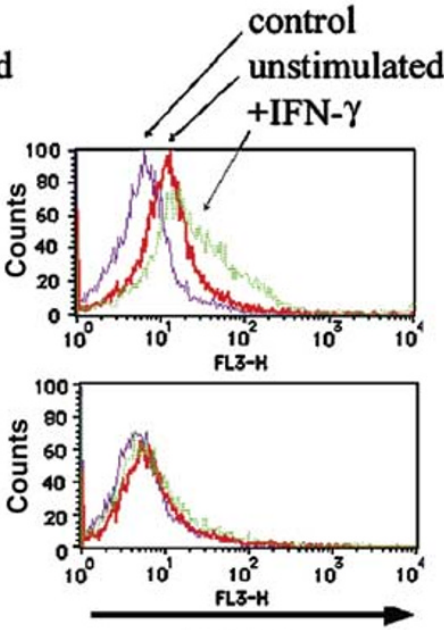

IL-18R $\alpha$

Figure 1 Expression of IL-12R and IL-18R genes in NK cells that were derived from B6- + / +, B6-mi/mi, or B6- $t$ g/tg mice. (a) Expression of IL-12R $\beta 1$, IL-12R $\beta 2$ IL-18R $\alpha$, and IL-18R $\beta$ genes in freshly isolated NK 1.1 ${ }^{+}$cells derived from B6- + / +, B6-mi/mi, or B6-tg/tg mice was examined, as measured by RT-PCR. Three independent experiments were performed, with comparable results: a representative experiments is shown. (b) Flow cytometric analysis of the expression of IL-12R $\beta 2$ and IL-18R $\alpha$ genes in freshly isolated NK $1.1^{+}$cells with or without IFN- $\gamma$ treatment that were derived from B6- $+/+$ or B6-mi/mi mice. Three independent experiments were performed, with comparable results: a representative experiments is shown.

a

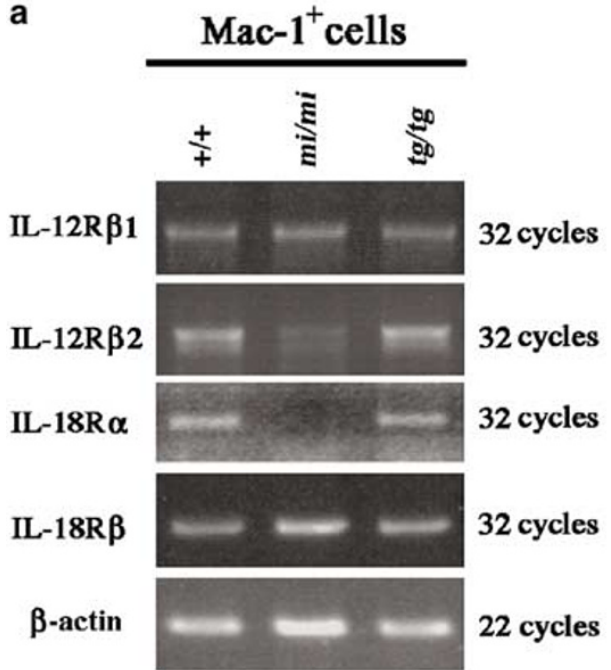

b
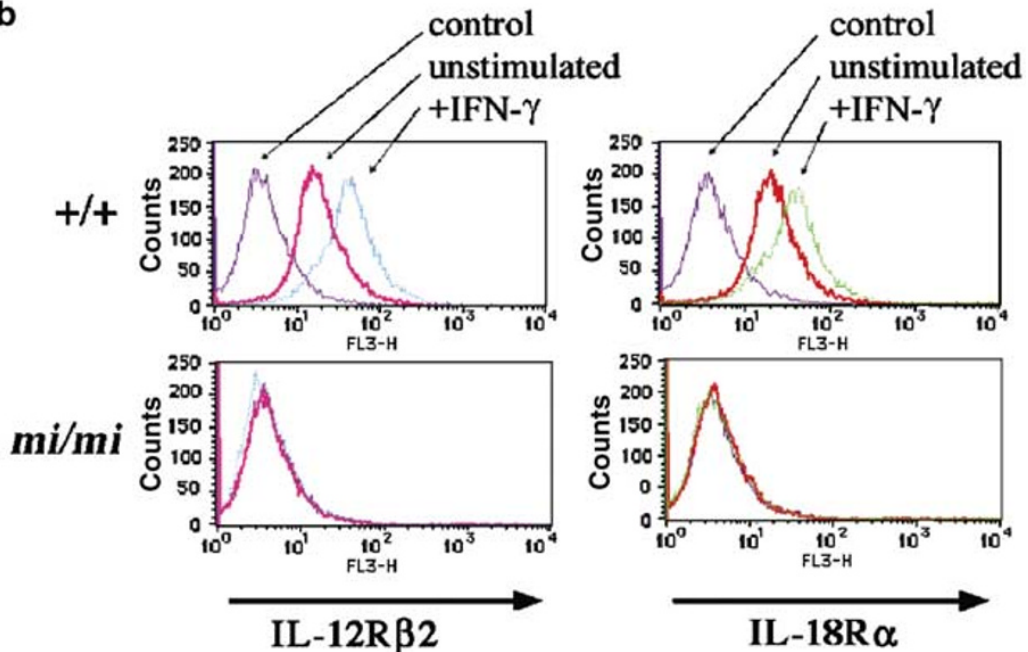

IL-18R $\alpha$

Figure 2 Expression of IL-12R and IL-18R genes in the macrophages of B6- + / , B6-mi/mi, or B6- $t g / t g$ mice. (a) RT-PCR analysis of the expression of IL-12R $\beta 1$, IL-12R $\beta 2$, IL-18R $\alpha$, and IL-18R $\beta$ genes in cultured Mac- ${ }^{+}$cells that were derived from B6- + / + , B6-mi/mi, or B6$\mathrm{tg} / \mathrm{tg}$ mice. Three independent experiments were performed, with comparable results: a representative experiments is shown. (b) Flow cytometric analysis of the expression of IL-12R $\beta 2$ and IL-18R $\alpha$ genes in cultured Mac- $1^{+}$cells with or without IFN- $\gamma$ treatment that were derived from B6- $+/+$ or B6-mi/mi mice. Three independent experiments were performed, with comparable results: a representative experiments is shown.

show essentially similar expression pattern of the IL-12R and IL-18R genes as well (data not shown).

\section{Impaired IFN- $\gamma$ Production of NK Cells and Macrophages Derived from B6-mi/mi Mice}

IL-12 and IL-18 enhance synergistically the production of IFN- $\gamma$ by NK cells and macrophages. ${ }^{18,22-27}$
Therefore, we analyzed the IFN- $\gamma$ production in NK cells and macrophages from B6- $+/+$ and B6-mi/mi mice. An enzyme-linked immunosorbent assay (ELISA) was used to measure the IFN- $\gamma$ production levels of freshly isolated or cultured NK $1.1^{+}$cells, peritoneal macrophages and cultured $\mathrm{Mac}^{-} 1^{+}$cells. IL-12 and IL-18 induced IFN- $\gamma$ production of freshly isolated and cultured NK $1.1^{+}$cells derived from B6- $+I+$ mice, and these cytokines functioned 
synergistically (Figure 3a,b). In contrast, the cells that were derived from B6-mi/mi mice showed significantly impaired IFN- $\gamma$ production (Figure 3a,b). In contrast to IL-12 and IL-18 stimulation, PMA-ionomycin-induced IFN- $\gamma$ production was comparable among cultured NK cells derived from B6- + / + or mi/mi mice (Figure 3b). Essentially similar results were observed for the macrophages. When B6-mi/mi peritoneal macrophages and cultured Mac-1 ${ }^{+}$cells were stimulated with IL-12 plus IL-18, the level of IFN- $\gamma$ production was significantly lower than that of the control (Figure 3c, d). IFN- $\gamma$ production by PMA-ionomycin stimulation was comparable among cultured Mac- $1^{+}$cells derived from $\mathrm{B} 6-+/+$ or $\mathrm{mi} / \mathrm{mi}$ mice (Figure 3d).

Reduced Pfn mRNA Induction by IL-12 and/or IL-18 in B6-mi/mi NK Cells

We have reported previously that the cytotoxic activity of splenic NK cells correlates well with the Pfn mRNA expression level in these cells. ${ }^{10}$ In addition, it has been reported that IL-12 enhances the expression of $\mathrm{Pfn}$ mRNA. ${ }^{31}$ Therefore, we examined the effects of IL-12 on the expression of Pfn mRNA in B6-mi/mi splenic NK cells. We
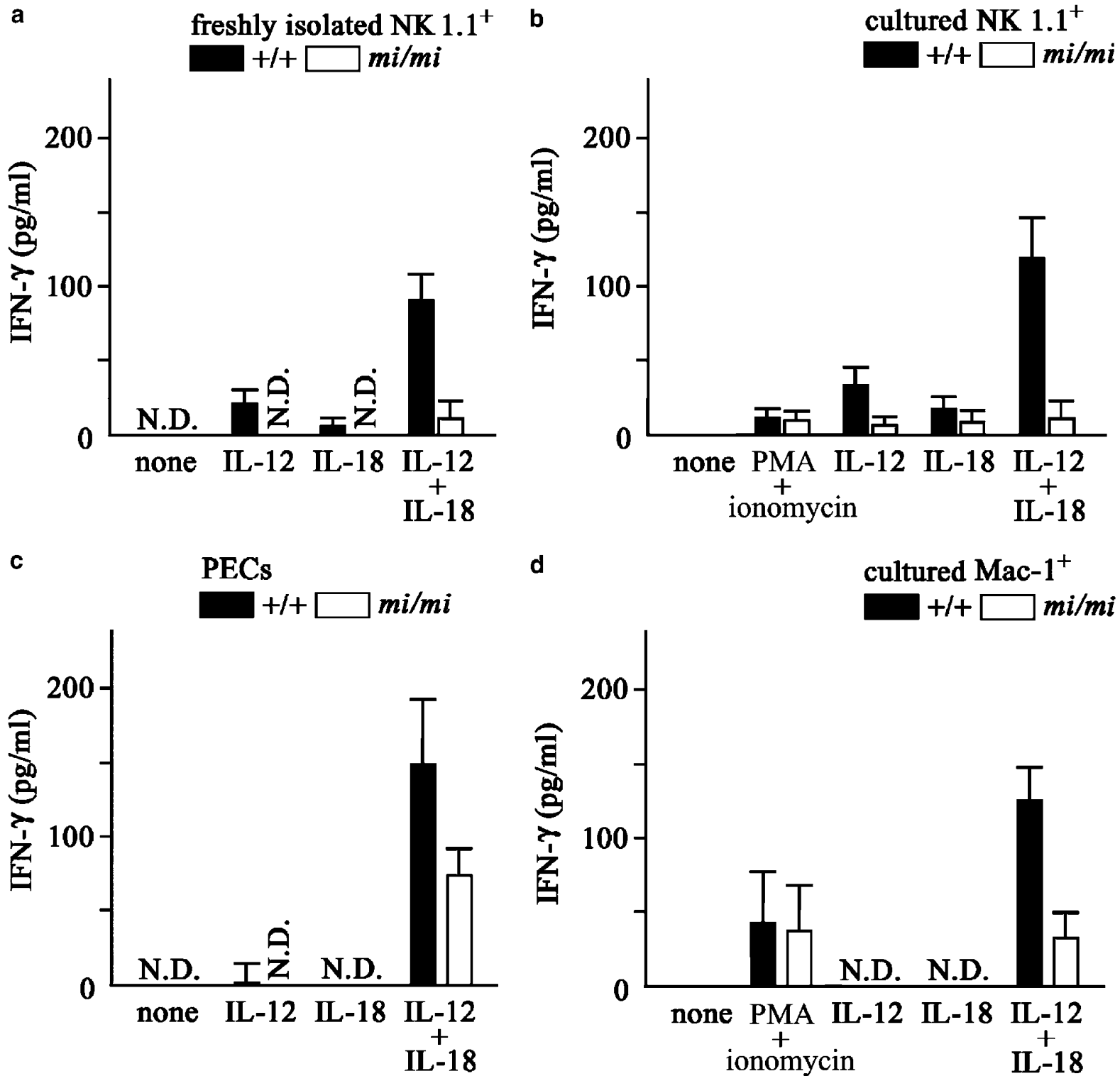

d
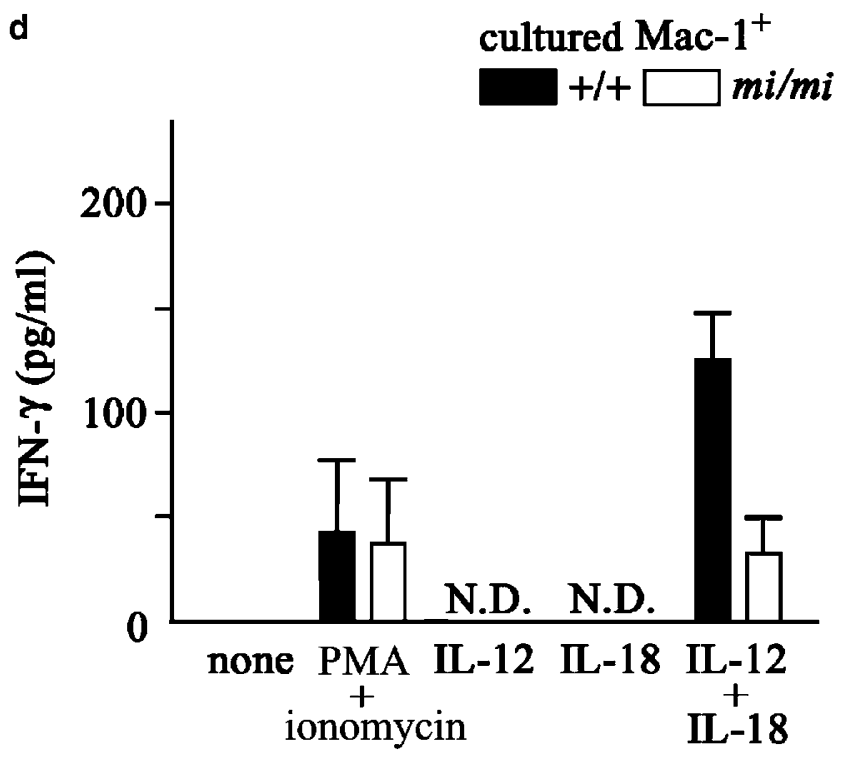

Figure 3 IFN- $\gamma$ production by NK cells and macrophages that were derived from B6- $+/+$, or B6-mi/mi mice. Freshly isolated NK $1.1^{+}$ cells (a), cultured NK cells (b), peritoneal macrophages (c), and cultured Mac-1 ${ }^{+}$cells (d) were cultured with IL-12, IL-18, or IL-12 plus IL-18 for 5 h. Cultured NK cells (b) and cultured Mac- $1^{+}$cells (d) were also cultured in the presence of PMA-ionomycin. The culture supernatants were subjected to ELISA. 


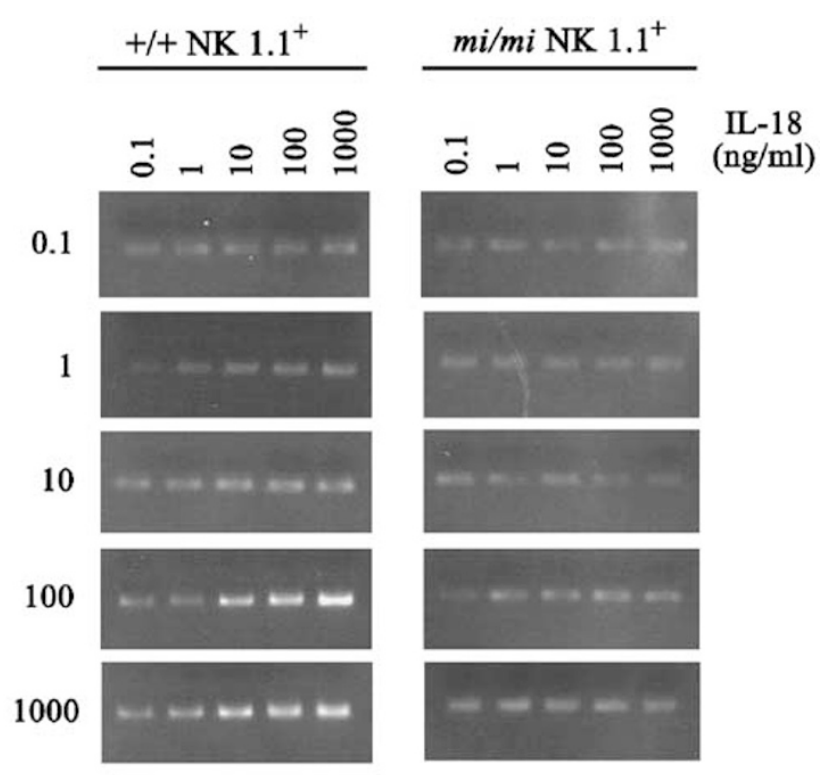

IL-12

(ng/ml)

Figure 4 Expression of the Pfn gene in cultured NK $1.1^{+}$cells that were derived from B6- + / + or B6- $\mathrm{mi} / \mathrm{mi}$ mice. RT-PCR analysis of Pfn gene expression in cultured NK $1.1^{+}$cells that were derived from B6- $+I+$ or B6-mi/mi mice. Each of the specimens used for estimating Pfn gene expression contained comparable amounts of the RT products, as assessed by the $\beta$-actin levels (data not shown). Three independent experiments were performed, with comparable results: a representative experiments is shown.

confirmed that IL-12 stimulation dose-dependently induced the transcription of Pfn mRNA in B6- $+/+$ NK cells. Although IL-18 alone induced only weak expression of Pfn mRNA. IL-18 synergized with IL12, to enhance the expression of Pfn mRNA (Figure 4). In contrast, neither IL-12 nor IL-18 increased the expression level of Pfn gene in B6-mi/mi NK cells. Furthermore, the stimulation of B6- $\mathrm{mi} / \mathrm{mi}$ NK cells with IL-12 plus IL-18 enhanced only weakly the expression of $\mathrm{Pfn}$ mRNA in B6-mi/mi NK cells (Figure 4).

\section{Discussion}

Several cytokines play important roles in NK cell development and activity (reviewed in Williams et $a l^{32}$ and Colucci et $a l^{33}$ ). For example, Flt3 (FMS-like tyrosine kinase 3) ligand, ${ }^{34} \mathrm{c}$-kit tyrosine kinase ligand, ${ }^{35}$ and IL- $7^{36}$ are important for the early stages of NK cell development. IL-2 and IL-15 play pivotal roles in NK cell maturation. ${ }^{37-39}$ Notably, IL-12 and IL-18 enhance NK activity. ${ }^{18,22}$ Neither IL-12 nor IL18 seem to be essential for NK cell development, since both IL-12-deficient and IL-18-deficient mice show normal NK $1.1^{+}$cell development. ${ }^{32}$

As is the case for IL-12-deficient and IL-18deficient mice, the B6-mi/mi mice showed normal
NK $1.1^{+}$cell development and significantly reduced NK activity. ${ }^{9,10}$ However, in contrast to the IL-12deficient and IL-18-deficient mice, the NK activity of B6-mi/mi mice was not recovered even after daily intraperitoneal injection of IL-18 (1000 ng) or IL-12 (100 ng) for 2 days ${ }^{22}$ (our unpublished data).

We also examined the responses of B6-mi/mi NK cells to IL-12 and IL-18. We reported previously that NK activity correlates with the expression level of Pfn mRNA in spleen-derived mononuclear cells after intraperitoneal injection of polyinosinic-polycytidylic acid (poly I:C). ${ }^{10}$ In comparison with B6$+/+$ mice, the B6-mi/mi mice showed significantly reduced levels of NK activity and Pfn gene expression. ${ }^{9,10}$ Since poly I:C stimulated the production of IL-12 by the macrophages, ${ }^{40}$ the decreased expression of the Pfn gene in B6-mi/mi NK cells may be attributed to the reduced production of IL-12 by poly I:C-stimulated macrophages. NK cells produce IFN- $\gamma$ in response to stimulation with IL-12 and IL18, and IL-12R $\beta 1$-deficient, IL-12R $\beta 2$-deficient, and IL-18R $\alpha$-deficient mice have been reported to show impaired IFN- $\gamma$ production following IL-12 or IL-18 stimulation. ${ }^{23-25}$ Similarly, the B6-mi/mi NK cells showed decreased IFN- $\gamma$ production in response to stimulation with IL-12, IL-18, or IL-12 plus IL-18. PMA-ionomycin stimulation also induces IFN- $\gamma$ production. ${ }^{30} \mathrm{~B} 6-\mathrm{mi} / \mathrm{mi}$ NK cells secreted a comparable level of IFN- $\gamma$ with that of B6- $+/+$ NK cells by PMA-ionomycin administration. These data show that the reduced production of IFN- $\gamma$ by B6- $\mathrm{mi} / \mathrm{mi}$ NK cells depends on the impaired responsiveness to IL-12 and IL-18, rather than the decreased IFN- $\gamma$ expression of B6- $\mathrm{mi} / \mathrm{mi} \mathrm{NK}$ cells. Taken together, our results suggest that the abnormal phenotype of B6$\mathrm{mi} / \mathrm{mi}$ NK cells is due to the impaired responses to IL-12 and IL-18.

The macrophage-lineage cells of B6-mi/mi mice showed abnormal phenotypes, such as osteopetrosis, decreased phagocytic capacity and decreased acid phosphatase activity. ${ }^{11-13}$ Macrophages produce IFN- $\gamma$ in response to stimulation with IL-12 and IL-18. ${ }^{26,27}$ In this study, we observed another abnormal phenotype of B6-mi/mi macrophages, that is, poor responses to IL-12 and IL-18. It seems likely that this phenotype is due to the reduced expression of IL-12R $\beta 2$ and IL-18R $\alpha$ genes in B6- $\mathrm{mi} / \mathrm{mi}$ macrophages.

The expression levels of IL-12R and IL-18R were reduced significantly in NK cells and macrophages that were derived from B6-mi/mi mice. These data indicate that the decreased responses to IL-12 and IL-18 of B6- $\mathrm{mi} / \mathrm{mi}$ NK cells and B6- $\mathrm{mi} / \mathrm{mi}$ macrophages are due to the reduced expression of the IL$12 \mathrm{R} \beta 2$ and IL-18R $\alpha$ genes. It is known that IL-12R is enhanced by IFN- $\gamma$, and IL-18R expression is upregulated by IL-12 signaling. ${ }^{14,15,41}$ Reduced expression of IL-12R and IL-18R was not recovered by exogeneous IFN- $\gamma$ in both B6-mi/mi NK cells and B6$\mathrm{mi} / \mathrm{mi}$ macrophages. Therefore, the decreased expression levels of IL-12R and IL-18R on B6-mi/mi 
mice is not due to the impaired production of IFN- $\gamma$, but is intrinsic to the mi mutation. In contrast to the B6-mi/mi cells, B6-tg/tg NK cells and B6-tg/tg macrophages showed normal expression patterns of the IL-12R $\beta 2$ and IL-18R $\alpha$ genes. This discrepancy indicates that although the simple absence of MITF does not affect the expression of the IL-12R $\beta 2$ and IL-18R $\alpha$ genes, the presence of mi-MITF results in reductions in the expression of these genes. The miMITF showed an inhibitory effect on the expression of various genes in cultured mast cells,,$^{7,42-44}$ as well as the loss of transactivation activity. ${ }^{3}$ Considering the inhibitory effects of the mi-MITF on mast cells, it is conceivable that the mi-MITF inhibits via similar molecular mechanisms the expression of the IL$12 \mathrm{R} \beta 2$ and IL-18R $\alpha$ genes in NK cells and macrophages.

The inhibitory effect of mi-MITF may be explained by the functional cooperation of mi-MITF with polyomavirus enhancer binding protein 2 /corebinding factor (PEBP2/CBF). We have reported previously that mi-MITF interactes with PEBP2/ $\mathrm{CBF}$, thereby inhibiting its transactivational activity. ${ }^{4}$ The database of the National Center for Biotechnology Information shows that PEBP2/CBF binding motifs are located in the promoters of the IL$12 \mathrm{R} \beta 2$ and IL-18R $\alpha$ gene. Thus, mi-MITF may inhibit PEBP2/CBF function, which results in the decreased expression of the IL-12R $\beta 2$ and IL-18R $\alpha$ genes.

In summary, the abnormal phenotypes that were observed for the NK cells and macrophages of B6$\mathrm{mi} / \mathrm{mi}$ mice may be attributed to impaired responses to IL-12 and IL-18. This impairment appears to be due to the decreased expression of the IL-12R $\beta 2$ subunit and IL-18R $\alpha$ genes in B6-mi/mi NK cells and B6-mi/mi macrophages.

\section{Acknowledgements}

We thank Mr M Kohara and Ms T Sawamura for technical assistance. This work is supported by grants from the Ministry of Education, Culture, Sports, Science and Technology.

\section{References}

1 Hodgkinson CA, Moore KJ, Nakayama A, et al. Mutations at the mouse microphthalmia locus are associated with defects in a gene encoding a novel basic-helix-loop-helix-zipper protein. Cell 1993;74: 395-404.

2 Steingrimsson E, Moore KJ, Lamoreux ML, et al. Molecular basis of mouse microphthalmia ( $\mathrm{mi}$ ) mutations helps explain their developmental and phenotypic consequences. Nat Genet 1994;8:256-263.

3 Morii E, Takebayashi K, Motohashi $\mathrm{H}$, et al. Loss of DNA binding ability of the transcription factor encoded by the mutant mi locus. Biochem Biophys Res Commun 1994;205:1299-1304.
4 Takebayashi K, Chida K, Tsukamoto I, et al. The recessive phenotype displayed by a dominant negative microphthalmia-associated transcription factor mutant is a result of impaired nuclear localization potential. Mol Cell Biol 1996;16:1203-1211.

5 Stechschulte DJR, Sharma R, Dileepan KN, et al. Effect of the mi allele on mast cells, basophils, natural killer cells, and osteoclasts in C57Bl/6J mice. J Cell Physiol 1987;132:565-570.

6 Ebi Y, Kasugai T, Seino Y, et al. Mechanism of mast cell deficiency in mutant mice of $\mathrm{mi} / \mathrm{mi}$ genotype: an analysis by co-culture of mast cells and fibroblasts. Blood 1990;75:1247-1251.

7 Ito A, Morii E, Kim D-K, et al. Inhibitory effect of the transcription factor encoded by the mi mutant allele in cultured mast cells of mice. Blood 1999;93: 1189-1196.

8 Seaman WE, Gindhart TD, Greenspan JS, et al. Natural killer cells, bone, and the bone marrow: studies in estrogen-treated mice and in congenitally osteopetrotic ( $\mathrm{mi} / \mathrm{mi}$ ) mice. J Immunol 1979;122:2541-2547.

9 Ito A, Kataoka TR, Kim D-K, et al. Inhibitory effect on natural killer activity of microphthalmia transcription factor encoded by the mutant mi allele of mice. Blood 2001;97:2075-2083.

10 Kataoka TR, Morii E, Oboki K, et al. Strain-dependent inhibitory effect of mutant mi-MITF on cytotoxic activities of cultured mast cells and natural killer cells of mice. Lab Invest 2004;84:376-384.

11 Graves III L, Jilka RL. Comparison of bone and parathyroid hormone as stimulators of osteoclast development and activity in calvarial cell cultures from normal and osteopetrotic $(\mathrm{mi} / \mathrm{mi})$ mice. J Cell Physiol 1990;145:102-109.

12 Steingrimsson E, Tessarollo L, Pathak B, et al. Mitf and Tfe3, two members of the Mitf-Tfe family of b HLH-Zip transcription factors, have important but functionally redundant roles in osteoclast development. Proc Natl Acad Sci USA 2002;99:4477-4482.

13 Chambers TJ, Loutit JF. A functional assessment of macrophages from osteopetrotic mice. J Pathol 1979; 129:57-63.

14 Trinchieri G. Interleukin-12 and the regulation of innate resistance and adaptive immunity. Nat Rev Immunol 2003;3:133-146.

15 Nakanishi K, Yoshimoto $\mathrm{T}$, Tsutsui $\mathrm{H}$, et al. Interleukin-18 is a unique cytokine that stimulates both Th1 and Th2 responses depending on its cytokine milieu. Cytokine Growth Factor Rev 2001;12:53-72.

16 Kobayashi M, Fitz L, Ryan M, et al. Identification and purification of natural killer cell stimulatory factor (NKSF), a cytokine with multiple biologic effects on human lymphocytes. J Exp Med 1989;170:827-845.

17 Presky DH, Yang H, Minetti LJ, et al. A functional interleukin 12 receptor complex is composed of two $\beta$-type cytokine receptor subunits. Proc Natl Acad Sci USA 1996;93:14002-14007.

18 Magram J, Connaughton SE, Warrier RR, et al. IL-12deficient mice are defective in IFN $\gamma$ production and type 1 cytokine responses. Immunity 1996;4:471-481.

19 Okamura H, Tsutsui H, Komatsu T, et al. Cloning of a new cytokine that induces IFN- $\gamma$ production by T cells. Nature 1995;378:88-91.

20 Parnet P, Garka KE, Bonnert TP, et al. IL-1Rrp is a novel receptor-like molecule similar to the type I interleukin1 receptor and its homologues T1/ST2 and IL-1R AcP. J Biol Chem 1996;271:3967-3970. 
21 Born TL, Thomassen E, Bird TA, et al. Cloning of a novel receptor subunit, AcPL, required for interleukin-18 signaling. J Biol Chem 1998;273:2944529450.

22 Takeda K, Tsutsui H, Yoshimoto T, et al. Defective NK cell activity and Th1 response in IL-18-deficient mice. Immunity 1998;8:383-390.

$23 \mathrm{Wu}$ C-Y, Ferrante J, Gately MK, et al. Characterization of IL-12 receptor $\beta 1$ chain (IL-12R $\beta 1$ )-deficient mice. J Immunol 1997;159:1658-1665.

$24 \mathrm{Wu} \mathrm{C}-\mathrm{Y}$, Wang $\mathrm{X}$, Gadina $\mathrm{M}$, et al. IL-12 receptor $\beta 2$ (IL-12R $\beta 2$ )-deficient mice are defective in IL-12mediated signaling despite the presence of high affinity IL-12 binding sites. J Immunol 2000;165: 6221-6228.

25 Hoshino K, Tsutsui H, Kawai T, et al. Generation of IL-18 receptor-deficient mice: evidence for IL-1 receptor-related protein as an essential IL-18 binding receptor. J Immunol 1999;162:5041-5044.

26 Puddu P, Fantuzzi L, Borghi P, et al. IL-12 induces IFN- $\gamma$ expression and secretion in mouse peritoneal macrophages. J Immunol 1997;159:3490-3497.

27 Munder M, Mallo M, Eichman K, et al. Murine macrophages secrete interferon $\gamma$ upon combined stimulation with inteleukin (IL)-12 and IL-18: a novel pathway of autocrine macrophage activation. J Exp Med 1998;187:2103-2108.

28 Fukao T, Frucht DM, Yap G, et al. Inducible expression of Stat4 in dendritic cells and macrophages and its critical role in innate and adaptive immune responses. J Immunol 2001;166:4446-4455.

29 Yang S, ZhangY, Ries WL, et al. Characterization of $\mathrm{M}-\mathrm{CSF}$ and its receptor in microphthalmic mice. Exp Hematol 1995;23:126-132.

30 Afkarian M, Sedy JR, Yang J, et al. T-bet is a STAT1induced regulator of IL-12R expression in naïve $\mathrm{CD}^{+}$ T cells. Nat Immunol 2002;3:549-557.

31 Salcedo TW, Azzoni L, Wolf SF, et al. Modulation of perforin and granzyme messenger RNA expression in human natural killer cells. J Immunol 1993;151: 2511-2520.

32 Williams NS, Klem J, Puzanov IJ, et al. Natural killer cell differentiation: insights from knockout and transgenic mouse models and in vitro systems. Immunol Rev 1998;165:47-61.
33 Colucci F, Caligiuri MA, Di Santo JP. What does it take to make a natural killer? Nat Rev Immunol 2003;3: 413-425.

34 McKenna HJ, Stocking KL, Miller RE, et al. Mice lacking flt3 ligand have deficient hematopoiesis affecting hematopoietic progenitor cells, dendritic cells, and natural killer cells. Blood 1999;95:3489-3497.

35 Colucci F, Di Santo JP. The receptor tyrosine kinase c-kit provides a critical signal for survival, expansion, and maturation of mouse natural killer cells. Blood 2000;95:984-991.

36 Puel A, Ziegler SF, Buckley RH, et al. Defective IL-7R expression in $\mathrm{T}^{-} \mathrm{B}^{+} \mathrm{NK}^{+}$severe combined immunodeficiency. Nat Genet 1998;20:394-397.

37 Kundig TM, Schorle H, Bachmann MF, et al. Immune responses in interleukin-2-deficient mice. Science 1993;262:1059-1061.

38 Kennedy MK, Glaccum M, Brown SN, et al. Reversible defects in natural killer and memory CD8 T cell lineages in interleukin 15-deficient mice. J Exp Med 2000;191:771-780.

39 Di Santo JP, Muller W, Guy-Grand D, et al. Lymphoid development in mice with a targeted deletion of the interleukin-2 receptor $\gamma$ chain. Proc Natl Acad Sci USA 1995;92:377-381.

40 Manetti R, Annunziatto F, Tomasevic L, et al. Polyinosinic acid: polycytidylic acid promotes $\mathrm{T}$ helper type 1-specific immune responses by stimulating macrophage production of interferon- $\alpha$ and interleukin-12. Eur J Immunol 1995;25:2656-2660.

41 Grohmann U, Belladonna ML, Vacca C, et al. Positive regulatory role of IL-12 in macrophages and modulation by IFN- $\gamma$. J Immunol 2001;167:221-227.

42 Ogihara H, Morii E, Kim D-K, et al. Inhibitory effect of the transcription factor encoded by the mutant $m i$ microphthalmia allele on transactivation of mouse mast cell protease 7 gene. Blood 2001;97:645-651.

43 Morii E, Ogihara H, Oboki K, et al. Inhibitory effect of the mi transcription factor encoded by the mutant mi allele on GA binding protein-mediated transcript expression in mouse mast cells. Blood 2001;97:3032-3039.

44 Ogihara H, Kanno T, Morii E, et al. Synergy of PEBP2/ $\mathrm{CBF}$ with $\mathrm{mi}$ transcription factor (MITF) for transactivation of mouse mast cell protease 6 gene. Oncogene 1999;18:4632-4639. 